Check for updates

Montreal, Canada

Cite this as: $B M J 2020 ; 370: \mathrm{m} 2850$ http://dx.doi.org/10.1136/bmj.m2850 Published: 15 July 2020

\section{Covid-19: At least eight doctors in Egypt arrested for criticising government response}

\author{
Owen Dyer
}

Doctors in Egypt who have complained about a lack of personal protective equipment (PPE) or have otherwise spoken out against the government's pandemic response have faced interrogation, arrest, or forced transfer to distant hospitals, according to international human rights monitors and the Egyptian Medical Syndicate, the doctors' union.

At least eight doctors, two hospital pharmacists, and six journalists have been arrested since the virus first hit Egypt in February. An intensive care doctor in Cairo, Ahmed Safwat, was arrested this month after writing on his Facebook page, "The government says that everything is fine and under control, but you enter hospitals and find the opposite.”

Ophthalmologist Hany Bakr was arrested after criticising Egyptian shipments of PPE to Italy and China on Facebook. Junior doctor Alaa Shaaban Hamida was arrested and charged with "joining a terrorist group" and "misusing social media" after she let a colleague use her phone to report a covid-19 case to the health ministry's hotline instead of hospital managers. She remains in detention despite being pregnant.

Egypt appears to be just past the worst of the first wave of the pandemic, with new daily cases slowly declining, though the death rate has yet to follow. Testing is sparse at 1318 tests per million people. Reported deaths so far stand at 3935, the highest in the Arab world and, until Egypt was passed by South Africa this week, the highest on the continent.

But while Egypt and South Africa have similar death tolls, the difference among health workers is stark. Six doctors have died in South Africa, 117 in Egypt.

In Egypt, as in many countries, the government has encouraged public displays of gratitude to the "white army" of health workers fighting the pandemic. But while the government offered cash bonuses to doctors willing to treat patients with covid-19, it is taking no chances with volunteers. In a country where most doctors do at least some private work to supplement meagre state income, all such work was banned. Only a fraction of the promised bonuses have been paid, doctors complain, and working on covid-19 wards is not optional.

In reports to Human Rights Watch, Amnesty International, and the Associated Press, doctors have complained about being forced to work even when sick. Several doctors shared messages from hospital administrators warning that absence from work would trigger a visit from the National Security Agency (NSA), which maintains staff on the covid-19 "crisis committees" established around the country.

In a voice recording obtained by the Associated Press, an administrator in the Nile Delta province of Beheira can be heard telling health workers that absentees would be treated like military deserters. "Even if a doctor is dying, he must keep working," he said, "or be subjected to the most severe punishment."

In another message, a Beheira hospital director describes absentees as "traitors," adding, "this will be treated as a national security matter-and you know how that goes in Egypt.”

Doctors at Al-Mounira hospital in Cairo, who resigned as a group after a young colleague died, were forced to retract their resignations after a visit from the NSA.

Forced transfers are another sanction. A doctor in Deyerb Negm in the Nile Delta who posted a video asking for PPE and eight pharmacists at Damanhour Medical National Institute who protested unsafe conditions were sent to work in distant provinces.

Earlier this month, Egypt's prime minister Mustafa Madbouly praised health workers for their "exceptional effort" in fighting the virus but then blamed "absenteeism and disobedience" on the part of doctors in some provinces for a recent spike in deaths.

Mohamed el-Fawal, treasurer of the Egyptian Medical Syndicate, demanded on Facebook that Madbouly apologise, and was arrested. A press conference organised by the doctors' union to protest was broken up by NSA agents.

"They arrest my colleagues to send us a message. I see no light on the horizon," said one doctor from the syndicate, speaking anonymously to the Associated Press. Another told Amnesty International, "They are forcing doctors to choose between death and jail." 